DOI: https://doi.org/10.47405/mjssh.v6i8.929

\begin{tabular}{|c|c|}
\hline$x_{i=1}$ & Malaysian Journal of Social Sciences and Humanities (MJSSH) \\
\hline $\begin{array}{l}\text { Malaysian Journal of } \\
\text { Socrai scciecces and }\end{array}$ & Volume 6, Issue 8, August 2021 \\
\hline (MJ-SSH) & e-ISSN : 2504-8562 \\
\hline & $\begin{array}{l}\text { Journal home page: } \\
\text { www.msocialsciences.com }\end{array}$ \\
\hline
\end{tabular}

\title{
Understanding the Relationship Between Youth Voluntary Organization, Leadership and Intergroup Relationship in Sabah, Malaysia
}

\author{
Mohd. Sohaimi Esa ${ }^{1}$, Romzi Ationg1, Mohd. Azri Ibrahim ${ }^{1}$, Abang Mohd. Razif Abang Muis' ${ }^{1}$, Irma \\ Wani Othman', Sirahim Abdullah' \\ 1Pusat Penataran Ilmu dan Bahasa, Universiti Malaysia Sabah (UMS)
}

Correspondence: Romzi Ationg (mrationg@ums.edu.my)

\begin{abstract}
If the youth voluntary associations' common goals are to be achieved, their leaders must embrace leadership ethics that are the most effective in leading and motivating people to actively execute their job. In carrying out their leadership role, it is also important to note that the leaders always required considering the role played by the factor calls intergroup relations. Accordingly, based on literature as well as documents review, this paper briefly discusses the importance of understanding the relationship between leadership ethics and intergroup relations in effort to consolidating youth development in Sabah. The paper thus shows that leadership ethics is a key determining factor in the attainment of youth voluntary common goals with consideration of intergroup relationship factor within the organization. Nevertheless, it is argued that a further study to be done for clarification on this matter.
\end{abstract}

Keywords: leadership, youth development, Sabah, volunteerism

\section{Introduction}

In this post-modern world, one of the challenges of youth development is to nurture the youth to be highly adaptable to all aspects in their life as well as in their daily activities. However, in many communities such as in Sabah, Malaysia, many youths spend most of their day along streets walks, shops and cafes, while youths, nowadays, should perceive their involvement in voluntary associations especially in youth voluntary associations as their human right. The youth participation in voluntary activities is not only a part of their development process as they acquire new knowledge and skills but it is also seen as a direct contribution to the national development efforts.

Reflecting from this point of view, the government as an enabler in the improvement of youth volunteerism has emphasized volunteerism among youth in most national blueprints as well as the Eighth Malaysia Plan, as cited in Surjit Singh et al. (2005a). The government is actively encouraging volunteerism among youngsters because volunteerism can be employed to reduce problems related to them. As reported by Surjit Singh et al. (2005a) Malaysia is also not immunized to social problems associated with a rapidly industrializing country, and having faced problems such as drug addiction, juvenile delinquency, and domestic violence.

Voluntarism among youngsters in Malaysia is promoted with the founding of various voluntary associations such as youth voluntary associations in the village level, youth voluntary association in the 
national level, animal rescue voluntary associations and ethnic groups voluntary associations. The voluntary associations in Malaysia, (especially in Sabah) can be formal, informal or ad hoc (Surjit Singh et al., 2005b). Surjit Singh et al. (2005b) also stated that formal volunteering comes in the form of formal enlistment to an organized group or institution with a well-defined social structure, role and function. In contrast, informal volunteering is engaging in voluntary action outside the domain of organized group or charitable associations. This includes extending help to an extended family or neighborhood.

Voluntary associations in Sabah are an independent, non-profit association formed to promote the spirit of voluntary service among Malaysians and provide opportunities for them to work as volunteers with communities in need at home and abroad. Most youth voluntary associations organize voluntary service programs in various fields, focusing particularly on sports, education, health, and community development work. The voluntary associations' activities are normally funded by contributions from individuals, corporate bodies and the government (Duguid, Slade \& Schugurensky, 2006).

Moreover, European Commission Youth (2010), McBride, Olate and Johnson (2008), and Barlett and Briges (1957) stated that the common goals of the youth voluntary associations are a person-centered development as well as human welfare: development of socially responsible citizen, development of self-independence, development of self-directed, improvement of self-reliance, and improvement of self-control. Specifically, in Malaysia, Siti Raba'ah (2005), and Ministry of Youth and Sports, Malaysia (2006) also stated that the common goals of the youth voluntary associations are to ensure that more youth become socially responsible citizens, self-independent, self-directed, self-reliant, and more self-controlled.

\section{What Need to be Done?}

To ensure the youth voluntary associations' common goals are achieved, their leaders must embrace leadership ethics that are the most effective in leading and motivating people to actively execute their job (Ationg, Esa, Ibrahim \& Muis, 2020; Ationg, 2001; Ationg, Zulhaimi, Ibrahim \& Hashim, 2018; Ationg, Othman, Esa, Tamring, Hajimin \& Hamid, 2021; Ationg, Esa, Othman, Shah, Yusoff, Ramlie \& Mokhtar, 2021; Ationg, Majumah, Bakar, Zulhaimi, Muda, Othman \& Muis, 2021; Ationg, Esa, Ibrahim, Shah, Yusoff, Othman \& Mokhtar, 2021). It can generate significant benefits for the associations, including enhanced innovation, creativity, and productivity (Valentine, 2001). Capturing these benefits, Jung \& Sosik (2002), Silverthorne (2001), and Duemer, Christopher, Hardin \& Olibas (2004) recognized that the availability of appropriate leaders can enhance a work group's performance, increase group members' job satisfaction, and reduce turnover intentions.

Thus, leaders must continuously seek to improve performance and enhance work group effectiveness to drive group competitiveness. The leaders also need to improve their morality and ethical aspects (Ationg, Esa, Ibrahim, Shah, Yusoff, Othman \& Mokhtar, 2021; Esa, Ationg, Ibrahim, Othman, Muis, Zulhaimi \& Muda, 2021; Esa, Ationg, Othman, Majumah, Bakar, Shah \& Yusoff, 2021; Ibrahim, Ationg, Esa, Muis, Othman, Yusoff, \& Mokhtar, 2021). Therefore, Ruiz, Ruiz, \& Martinez (2010) stated that due to the importance of leaders in human groups as well as in youth voluntary associations, the concept of leadership is one of the topics that have the most intrigued research for centuries. However, aside from the high number of studies about leadership (Bass, 1990 In Ruiz, Ruiz, \& Martinez, 2010) only a few are concerned with moral dimension of leadership as a factor to achieve the association's goals, while the moral dimension of the leaders is the main aspect that must be studied.

Cummins (1998) in his study on leadership for volunteer in the United States of America found that the failure of voluntary associations is commonly attributed to a lack of leadership in the organization as well as an association. This study also revealed that volunteers are attracted to certain organizations as well as an association for a variety of reason such as intrinsic (doing something when they believe in the leadership) and extrinsic motivation (doing something for an expected payoff). Whichever the case, the volunteer expects to fulfill an association's mission if the vision and mission of the associations are clearly articulated and can bring about benefits. However, if the leader is only using them to achieve 
personal aims then they would not involve in any voluntary activities. Thus, trust has been a central binding force of human relationship (Kankainen, 2009) and it can be a major factor that determines the common goal achievement of voluntary associations.

In accordance, the members of a voluntary association will be actively involved in any voluntary associations' activities if they think that the leader can be trusted. The trusted leader in general exists when the leader is an ethical person. Leadership ethics are often referred to fair management practices powered by strong principles. In general, ethical leaders set reasonable yet high standards for their followers to which they also adhere. They represent an association such as youth voluntary association core values and serve as role models to others. In contrast, unethical leadership occurs when the leader acts out of a personal sense of morals or on emotions such as jealousy or anger rather than what is best for the association. An ethical leader is not a perfect leader, but is much needed to achieve the association's goals.

Medonca and Kanungo (2007) stated that the leader's motives, influenced strategies, and character are extremely needed to achieve the common goals of human welfare at personal, organizational, and societal level. Thus, leaders must use their power with restraint, since it always holds the potential for treating others as less than fully human. If they do not use their power according to the needs of the association, it would create problems. One of the problems is that every single association member would face the potential of not achieving the common goals of the association where they belong to as well as the human welfare.

However, there is no specific discussion or even research findings on the influences of ethical leadership towards the achievement of common goals belonging to the association (youth voluntary association) especially when there is the importance factor is involved such as intergroup relation factor. In general, the intergroup relation is one of the factors that may pull the leaders to become ethical leaders or otherwise which it can bring about greater achievement of the associations' common goals.

According to Texeira, Demoulin and Yzerbyt (2011), in likelihood, leaders are representative to their group. Most of the leaders are selected due to their ability to minimize both intergroup and intragroup differences, and maximizes either intergroup or intragroup ones. Moreover, the leader is needed to minimize intergroup and intragroup conflicts, and maximize intergroup and intragroup cooperation. However, Toscano (1999) stated that these tasks could not be achieved if the leaders do not possess strong ethical foundation.

In the first place, it would be practically impossible to minimize both intergroup and intragroup conflict if the person selected as the leader is not able to do his job ethically. The leader also must be able to motivate the group members in identifying an important common issue and work towards common goal without a sense of bias while serving as a role models to his followers as well as according to Lee (2002), groups must identify an important common issue and work towards common goals.

Accordingly, recent studies show that there is a relationship between intergroup relation and personality traits as well as the possibility that an individual becomes an ethical person or otherwise. Krueger et al (2008) found that there is an impact to intergroup relation on the personality traits. Eichar (2010) also found similar result. There are also other studies that obtained a somewhat similar finding such as the study by Crisp and Turner (2009), Grzeisk-Feldman (2007), and Jackson, Joshi and Erhardt (2003). These findings are preliminary showing that there is the influence of the intergroup relation towards the youth voluntary leadership personality traits as well as a possibility that an individual becomes an ethical person or otherwise.

Based on this minimal information on the importance of leadership ethic in order to achieve the common goals of the youth voluntary association, this research is initiated to discuss the current phenomenon of youth voluntary associations in Sabah, Malaysia which is concerning youth leadership ethics and the intergroup relation. This paper discusses the relationship between intergroup relation and 
the effectiveness of leadership ethics as a toll to achieve youth voluntary association's common goals in the state of Sabah.

\section{Youth Voluntary Association in Sabah}

Sabah is a Malaysian state located on the northern region of the island of Borneo. In 2008 Sabah's population reported to 3.32 million, and increased to 3.29 million in 2009 (Department of Statistics, Sabah, 2009). Sabah indeed has one of the highest population growth rates (average annual growth rate) in the country that is 3.92 percent (Department of Statistics, Sabah, 2009).

The people of Sabah are divided into two officially recognized citizen group namely Malaysian citizen and non-Malaysian citizen. Malaysian citizen then is divided into two (2) main ethnic groups namely indigenous or Bumiputera, and non-indigenous (Department of Statistics, Sabah, 2009). The largest indigenous ethnic group is the Kadazandusun followed by the Bajau and Murut. The largest nonindigenous ethnic group is the Chinese are most Chinese in Sabah is concentrated primarily in Kota Kinabalu followed by Sandakan and Tawau respectively. Meanwhile, there are a very small number of Indians and other South Asians in Sabah as compared to other parts of Malaysia. Collectively, all persons originating from Sabah are known as Sabahans, and also identify themselves as such (Sabah, 2007).

Malay language is the national language spoken across ethnicities, although the spoken Sabahan dialect of Malay differs much in inflection and intonation from the West Malaysian version, having more similarity to the Indonesian Malay pronunciation. English, Mandarin as well as the Chinese dialects of Hakka and Cantonese are widely understood. In addition, the Kadazandusun, Bajau, Murut and other minor races also have their distinct ethnic languages (Sabah, 2007).

The Department of Statistics, Sabah (2009) reported the number of Sabahan youths in 2008 was $1,427,700$ with most of them residing in both rural and urban areas. This number has increased from year to year as the population health status improved. In 2009, the Department of Statistics, Sabah (2009) reported that the number of Sabahan youth was 1,459,600. The increase of youth population has somewhat made the urban and rural areas relatively unsafe due to more youths getting involved in unproductive and dangerous activities such as alcohol consumption and drug addiction. Such vices/activities would indubitably cause the state to encounter various social issues if no efforts are taken to curb these matters as youth are the further leaders of the world (Chigunta, 2002).

In view of Sabah's increasing number of youths, the government has been actively promoting youth voluntary association as well as grooming brilliant future leaders to steer them away from social problems. Daily Express (Friday, 29th April, 2011, p. 7) reported that under the State Budget, 2011, RM210.81 million had been allocated for youth development in Sabah. This fund has been distributed to four ministries and several departments to develop Sabah youths. A total of RM10.5 million has been allocated for Youth and Sports Ministry which is the biggest approved fund for the ministry as compared to the fund in 2010 (RM4.8 million) and 2009 (RM3.8 million). In accordance, youth development, with its adequate policy and support, can become a powerful force in empowering large numbers of youths in Sabah to play active roles in sustainable programs or national development activities, and to serve as major contributors to the overall progress of their country. The government agencies' mission in promoting such youth voluntary association is to strengthen and expand existing government and non-government youth programs and help set up new ones that enable girls and boys; and young men and women to become productive and contributing citizens to their local communities. These voluntary associations in general aim to promote a person-centered development (European Commission Youth, 2010; McBride, Olate \& Johnson, 2008; Siti Raba'ah, 2005; Ministry of Youth and Sports, Malaysia, 2006; Barlett \& Briges, 1957). However, this aim could not be achieved if there are no youth leaders that can be convinced to help achieve this goal. Thus, the phenomenon shows that ethical leadership is needed to organize their followers to be actively involved in development activities as according to Renesch (2001) leadership (who upholds ethics) is needed by many people as the leadership is one of the most elusive keys to association success. 
Moreover, Bass (1990), Haywood and Wygal (2009) cited that ethical leadership is one who is professional, possesses good character traits, knows oneself well, has knowledge on human nature, knows one's own job, provides direction, implementing skill and capable in motivating the followers. The leadership ethics also refers to an interactive conversation that pulls people toward becoming comfortable with the language of personal responsibility and commitment and is not just for people at the top (Bennis, 2000). Ethical leadership which is often referred to effective leadership is applicable to all facets of youth life as well as a competency that they can learn to expand their own perspective, set the context of a goal, understand the dynamics of human behavior and take the initiative to get to where they want to be. Through discovering who they are (youths) and their life's work, they will develop the self-awareness and confidence required to lead the associations in achieving its common goals.

According to Emmet and Murphy (2005), leadership is the process of directing the behavior of others towards the accomplishment of some common objectives. Leadership is influencing people to get things done and doing it willingly (Bass \& Avolio, 1995). Bennis (2000) also cited that as an element in social interaction, leadership as well as an effective leadership, is a complex activity involving a process of influence, factors who are both leaders and followers, and a range of possible outcomes such as the achievement of goals, but also the commitment of individuals to such goals, and the enhancement of group cohesion.

The other term related to leadership is its attributes, which according to Goleman, Boyatzis and McKee (2007) it is the inner or personal qualities that constitute effective leadership. Goleman, Boyatzis and McKee (2007) also stated that this attribute including such characteristics namely values, characters, motives, habits, traits, style, behaviors, and skills. Therefore, the most important quality of leadership, the one quality for which everybody wants to be known, is extraordinary performance, with the goal of achieving extraordinary results. This means, people describe leadership to those men and women who they feel can most enable them to achieve important goals or objectives (Renesch, 1994).

Thus, leadership ethics which involve leading in manner that respects the right and dignity of others (Trevino, Brown \& Hartman, 2003) play greater roles to achieve associations' common goals. Trevino, Brown and Hartman (2003) also recited that ethical leader who demonstrates a level of integrity is important in order to stimulate a sense of leader's trustworthiness which is important to the followers to accept the vision of the leader (to achieve the association goals). According to Resick, Hanges, Dickson and Mitchelson (2006) the leaders have the responsibility to ensure standards of moral and ethical conduct which would makes them good or even become effective leaders (competent and able to transform people ethically).

Trevino, Brown \& Hartman (2003) stated that leaders who are ethical are generally people-oriented. Ethical leadership is also aware on the impacts of their decision towards others (Watts, 2008). Such credibility are of course would make them use their social power to serve the greater good instead of self-serving interests. It then often makes them being referred to a charismatic leadership which able to lead the followers to achieve the association goals (Dirk \& Ferrin, 2002).

\section{The Leaders and Youth Voluntary Organization in Sabah}

The kind of leadership mentioned above is not always available in every part of the world (Argyris, 1976). According to Winston (2007) there is evidence of a crisis or potential crisis in ethical leadership and decision making in nearly every sector of professional life, both organizationally and societal. Winston (2005) also stated that many of the most widely publicized cases of ethical abuses have involved large corporations and the "misuse of company resources, misrepresentation of financial performance, and aggressive and illegal marketing practices". It means one of the impacts of ineffective leadership that may occur is the potential existence of inefficiency management techniques used by people to manage certain resources which may lead to wastage of needed as well as natural resources. In accordance, there is a factor associated with the availability of leadership ethics that is 
intergroup relation. Thus, the leadership ethics are reflected by the emergence of intergroup relation within youth voluntary association. Therefore, it has never been known whether the youth leadership pursuing ethics when performing the given task or otherwise due to the emergence of intergroup relation. It has also never been known whether the effectiveness of youth leadership ethics as a tool to achieve the youth voluntary associations' common goals is related to the emergence of intergroup relation or otherwise.

In general, sub groups in youth voluntary associations in Sabah, Malaysia are formed when there are some members who are more interested in a closer relationship or harmony with a person or group of individuals as compared to another person or group of individuals in society. This condition is often occurred due to the nature of certain individuals who choose friends according to their needs (Liu, $2004 ; 2010)$. Preferred partners or friends typically include individual or group of individuals who have similar backgrounds (Abrams, Marques, Bown \& Henson, 2000; Sheepers, Spears, Doosje, \& Manstead, 2003). This usually involves demographic and socioeconomic factors such as role in the association, age, gender, residence, educational level, marital status, occupation, and income. Texeira, Demoulin and Yzerbyt (2011) stated that not all group members are equal within a group. Some are perceived as highly typical and normative group members whereas others occupy a more peripheral position or could even be considered deviant group members. Thus, based on this phenomenon, subgroups will eventually be formed in the youth voluntary associations in Sabah itself.

These sub-groups will interact with each other and this is known as intergroup relations in youth voluntary associations in Sabah, Malaysia. The intergroup relation in youth voluntary organizations in Sabah, Malaysia can be characterized by intergroup conflict or intergroup cooperation. Whether the intergroup relation in youth voluntary associations are characterized by conflict or cooperation, it is the responsibility of the youth voluntary association leaders to carry out their duties in an effort to achieve its common goals while addressing the problem that may associate with this factor (intergroup relation).

Hence, questions arise concerning the youth leadership ethics in Sabah. For instance, are they really effective in carrying out tasks due to the concentration on pursuing ethics in relation to the emergence of intergroup relation? The question also arises on whether there are the influences of the intergroup relation towards the youth leadership ethics or otherwise? Since the Sabah state government has increasingly motivated and encourages the youths to get involved in youth voluntary association activities, it should be of interest to encourage and acknowledge the importance of all parties to plays significant role to such ambition. For this reason, it is argued that effort for do so is by now can be described as necessary. Such responsibility is required a positive response from the researchers.

\section{Conclusion}

This paper has discussed the existing literature on the importance of leadership ethics in the attainment of youth voluntary organization in Sabah, Malaysia. It also discusses the importance of other factor in an effort to attain such aspiration namely intergroup relations. Therefore, based on literature as well as documents review, this paper noticed the significance of leadership ethics in an effort to attain youth voluntary common goals and that such aspiration required an account of intergroup relationship factor within the organization. This is a preliminary finding, and for this reason this paper suggests a further study to be done on this matter.

\section{Acknowledgment}

We gratefully acknowledge that this paper wouldn't be produced and publishable without the research grant provided by the UMS 


\section{References}

Abrams, D., Marques, J.M., Bown, N. \& Henson, M. (2000). Pro-norm and anti-norm deviance within and between groups. Journal of Personality and Social Psychology, 78, 906-912.

Argyris, C. (1976) Increasing Leadership Effectiveness, New York, NY: Willey.

Ationg, R., Esa, M., Ibrahim, M. \& Muis, A.M.R.A (2020). Menyingkap polemik peralihan kuasa secara luar biasa mengikut perspektif demokrasi berparlimen. Malaysian Journal of Social Sciences and Humanities (MJSSH), 5(11), 43 - 53.

Ationg, R. (2001). Keberkesanan kepimpinan tempatan dalam aktviti pembangunan desa di daerah Kudat. Unpublished Master Thesis, Universiti Putra Malaysia, Malaysia.

Ationg, R., Zulhaimi, N.A., Ibrahim, M.A. \& Hashim, J. (2018). Leaders' animosity and leaders' enviousness: An analysis on factor associated with the growing tense ethnic relations in Sabah, Malaysia. Journal of Advanced Research in Social and Behavioral Sciences, 11(1), 75-81.

Ationg, R., Othman, I.W., Esa, M.S., Tamring, B.A.M., Hajimin, M.N.H.H. \& Hamid, J.A. (2021). Etika Kepemimpinan untuk Pembangunan Mapan Persatuan Belia Sukarela di Malaysia. International Journal of Law, Government and Communication, 6(23), 171-185.

Ationg, R., Esa, M.S., Othman, I.W., Shah, M.K.M., Yusoff, M.S., Ramlie, H. \& Mokhtar, S. (2021). Understanding the Challenges and the Opportunities Associated with Leadership Development for Students of Higher Learning Institution in Sabah, Malaysia. International Journal of Education, Psychology and Counseling, 6(39), 127-136.

Ationg, R., Majumah, A.S.A.R., Bakar, A.L.A., Zulhaimi, N.A., Muda, N., Othman, I.W. \& Muis, A.M.R.A. (2021). Memahami Kepemimpinan Sebagai Elemen Penting Dalam Sektor Pendidikan Berasaskan Tinjauan Literatur. Journal of Islamic, Social, Economics and Development (JISED), 6(38), 1-10.

Ationg, R., Esa, M.S., Ibrahim, M.A., Shah, M.K.M., Yusoff, M.S., Othman, I.W. \& Mokhtar, S. (2021). Trends, Potential and Challenges of HLI's Leadership During Covid-19 Pandemic. Journal of Islamic, Social, Economics and Development (JISED), 6(38), 11-17.

Bartlett, W.H. \& Bridges, B. (1957). Annals of the American. USA: American Academy of Political and Social Sciences.

Bass, B.M. \& Avolio, B.J. (1995). MLQ Multifactor Leadership Questionnaire for Research: Premission Set. Redwood City, CA: Mindgarden.

Bass, B.M. (1990). From transactional to transformational leadership: learning to share the vision. Organizational Dynamics, 18(3), 19-31.

Bennis, W. (2000). Leaders: The Strategies for Taking Charge. New York, NY: Addison-Wesley.

Chigunta, I. (2002). The socioeconomic situation of youth in Africa: Problem, prospects and option. The socioeconomic situation of youth in Africa, July.

Crisp, R.J. \& Turner, R.N. (2009). Can imagined interactions produce positive perceptions? Reducing prejudice through simulated social contact. American Psychologist, 64(4), 231-240.

Cummins, R. (1998). Leadership for Volunteers: The way it is and the way it could be. Extension Journal, 36(5), October.

Daily Express (2011). RM10.5mil to fund activities of youths in Sabah. Daily Express, Friday, 29th April, 2011, page 7.

Department of Statistics, Sabah (2009). Yearbook of Statistics, Sabah, 2009. Kota Kinabalu: Department of Statistics, Sabah, Malaysia.

Department of Statistics, Malaysia (2009). Statistics Handbook, Malaysia, 2009. Putrajaya: Department of Statistics, Malaysia.

Dirks, K.T. \& Ferrin, D.L. (2002). Trust in leadership: Meta-analytic findings and implications for research and practice. Journal of Applied Psychology, 87, 611- 628.

Duguid, F., Slade, B. \& Schugurensky, D. (2006). Unpaid work, informal learning and volunteer cultures. Paper presented at the 36th annual SCUTERA conference, 4-6 July 2006, Trinity and All Saints College, Leeds.

Duemer, L.S., Christopher, M., Hardin, E. \& Olibas, L. (2004). Case study of characteristics of effective leadership in graduate student collaborative work. Education Chula Vista, 124, 721726. 
Eischer, V. (2010). Friend of foe? Value preferences and the association between intergroup relations and out-group attitudes and perception. Unpublished PhD Dissertation, Fakultät der Universität, Freiburg (Schweiz).

Emmet C.M. \& Murphy, M.A. (2005). Leading on the Edge of Chaos. New York: Prentice Hall Inc.

Esa, M.S., Ationg, R., Ibrahim, M.A., Othman, I.W., Muis, A.M.R.A., Zulhaimi, N.A. \& Muda, N. (2021). Elemen Kepimpinan Dalam Kursus Teras Universiti: Kajian Kes Dalam Kalangan Pelajar Universiti Malaysia Sabah. Journal of Islamic, Social, Economics and Development (JISED), 6(38), 18-29.

Esa, M.S., Ationg, R., Othman, I.W., Majumah, A.S.A.R., Bakar, A.L.A., Shah, M.K.M. \& Yusoff, M.S. (2021). Gaya Kepimpinan Tun Razak Menjana Aspirasi Celik Minda Politik Dalam Kalangan Pelajar Institusi Pengajian Tinggi Di Malaysia. Journal of Islamic, Social, Economics and Development (JISED), 6(38), 30 - 44.

Goleman, D., Boyatzis, R. \& McKee, A. (2007). The New Leaders. Harvard: Harvard Business School Press.

Grzesiak-Feldman, M. (2007). conspiract thinking and state-trait anxiety in young Polish adults. Psychological Reports, 100(1), 199-202.

Haywood, M.E. \& Wygal, D.E. (2009). Ethics and professionalism: Bringing the topic to life in the classroom. Journal of Accounting Education, 27(2), 71-84.

Ibrahim, M.A., Ationg, R., Esa, M.S., Muis, A.M.R.A., Othman, I.W., Yusoff, M.S. \& Mokhtar, S. (2021). Pengetahuan Terhadap Ilmu Perlembagaan, Undang-Undang Dan Rukun Negara Dalam Konteks Kepimpinan: Kajian Kes Pelajar Universiti Malaysia Sabah (UMS). Journal of Islamic, Social, Economics and Development (JISED), 6(38), 45 - 59.

Jackson, S.E., Joshi, A. \& Erhardt, N.L. (2003). Recent research on team and Organizational diversity: SWOT analysis and implications. Journal of Management, 29(6), 801-830.

Jung, D.I. \& Sosik, J.J. (2002). Transformational leadership in work groups: The role of empowerment, cohesiveness and collective efficacy on perceived group performance. Small Group Research, 33, 313-336.

Kankainen, T. (2009). Voluntary associations and trust in Finland. Research on Finnish Society, 2, 57.

Krueger, J.I., Hall, J.H., Villiano, P. \& Jones, M.C. (2008). Attribution and categorization effects in the representation of gender stereotypes. Group Process and Intergroup Relations, 11(3), 401414.

Liu, J.H. (2010). A Cultural perspective on intergroup relations and social identity. International Association for Cross-Cultural Psychology. Retrieved from http://orpc.iaccp.org/index.php.

Liu, J.H. (2004). A cultural perspective on intergroup relations and social identity. Center for CrossCultural Research, Western Washington University, Bellingham, Washington USA. Retrieved from http://www.ac.wwu.edu/ culture/liu.htm.

Lee, K. S. (2002). Building intergroup relations after September 11. Analysis of Social Issues and Public Policy, 131-141.

McBride, A.M., Olate, R. \& Johnson, L. (2008). Youth volunteer services in Latin America and Caribbean: A regional assessment (CSD Research Report RP 08-05). St. Louis: Centre for social development, Washington University.

Medonca, M. \& Kanungo, R.N. (2007). Ethical Leadership. New York: Open University Press.

Ministry of Youth and Sport, Malaysia (2006). Akta Pertubuhan Belia dan Pembangunan Belia 2006. Putrajaya: Kementerian Belia dan Sukan Malaysia.

Renesch, J. (1994). Leadership in a New Era: Visionary Approaches to the Biggest Crisis of Our Time. San Francisco: New Leaders Press.

Renesch, J. (2001). Conscious Leadership: Taking Responsibility for Our Better Future. LOHAS Weekly Newsletter, March 1.

Resick, C.J., Hanges, P.J., Dickson, M.W. \& Mitchelson, J.K. (2006). A cross-cultural examination of the endorsement of ethical leadership. Journal of Business Ethics, 63, 345-359.

Ruiz, P., Ruiz, C. \& Martinez, R. (2011). Improving the "leader-follower" relationship: Top manager or supervisor? The ethical leadership trickle-down effect on follower job response. Journal of Business Ethics, 99(4), 587-608. 
Sheepers, D., Spears, R. Doosje, B. \& Manstead, A.S.R. (2003). Two function of verbal intergroup discrimination: identity and instrumental motives as aresult of group identification and treat. Personality and Social Psychology Bulletin, 29, 568-577.

Silverthorne, C. (2001). A test of the Path-Goal Leadership Theory in Taiwan. Leadership \& Organizational Development Journal, 22(4), 151-158.

Siti Raba'ah Hamzah (2005). Sustainability of youth organizations and the role of leaders as agent of change. Unpublished Thesis for Master of Science, Faculty of Educational Studies, Universiti Putra Malaysia, Serdang, Selangor, Malaysia.

Sabah (2007). Year Book of Statistic, 2006. Kota Kinabalu: Department of Statistics, Sabah.

Surjit Singh, U.S, Sail, R.M., Abu Samah, B., Tajuddin Shah, R.A. \& Lumayag, L.L. (2005a). Encouraging voluntary work among public service retiree: How policy intervention can help. Pertanika, Journal of Social Science and Humanituies, 13(2), 219-230.

Surjit Singh, U.S, Sail, R.M., Abu Samah, B., Tajuddin Shah, R.A. \& Lumayag, L.L. (2005b). To volunteer or not to volunteer: The case of Malaysian public service retirees. Pertanika, Journal of Social Science and Humanituies, 13(2), 199-209.

Texeira, C.P., Demoulin, S. \& Yzerbyt, V.Y. (2011). Choosing the best means to an end: The influence of ingroup goals on the selection of represantatives in intergroup negotiations. Journal of Experimental Social Psychology, 47, 228-234.

Toscano, R. (1999). The face of the other: Ethics and intergroup relations. In Wadlow, R.V.L. (ed.). The Handbook of interethnic coexistence. New York, NY: Continuum.

Trevino, L.K., Brown, M. \& Hartman, L.P. (2003). A qualitative investigation of perceived executive ethical leadership: Perceptions from inside and outside the executive suite. Human Relations, 56(1), 5-37.

Valentine, S. R. (2001). A path analysis of gender, race, and job complexity as determinants of intention to look for work. Employee Relations, 23(2), 130-138.

Watts, T. (2008). Business Leaders' Values and Beliefs Regarding Decision Making Ethics. Los Angeles, CA: LULU.

Winston, M. D. (2005). Ethical leadership: Professional challenges and the role of LIS education. New Library World, 106(5), 234-243.

Winston, M. D. (2007). Ethical leadership and ethical decision making: A meta-analysis of research related to ethics education. Library \& Information Sciences Research, 29(2), 230-251. -(2010). European Commission Youth. Estonia: Viljandi, YMCA 